\title{
Integrating Emailing Tasks into EFL Reading Comprehension Classrooms
}

\author{
Khalil Motallebzadeh \\ Islamic Azad University, Torbat-e-Heidarieh Branch, Iran \\ Email: k.motalleb@iautorbat.ac.ir; kmotallebz@gmail.com
}

\begin{abstract}
This study investigated the efficacy of integrating emailing tasks into EFL pre-intermediate reading classrooms. While students in experimental groups were provided with ten passages (ten tasks for each passage) through emails during 15 sessions of instruction, control groups were treated through similar passages and tasks in print. The instruments implemented were (a) Interchange/Passages Objective Placement Test C (IPOPT/C) (70 items) as the homogenizing test, (b) an Information Technology (IT) Inventory (58 items); and (c) a teacher-made posttest (30 items) including two sections of seen (10 tasks) and unseen (20 tasks) passages. Results showed a significant difference between students' performances on IPOPT/C (reading section) and the seen section of the posttest in emailing groups and those in control groups $(\mathbf{p} \leq \mathbf{0 . 0 5})$. Findings, however, revealed no significant difference between both groups' performances in unseen section of the posttest. As the results of this study show, designing effective emailing tasks can contribute to the improvement of second language reading comprehension ability.
\end{abstract}

Index Terms - reading comprehension, technology enhanced language learning, electronic mailing, emailing tasks

\section{INTRODUCTION}

With the advent of new technologies all over the world, novel needs have been introduced to the educational contexts. Nowadays, learners' new expectations have caused language schools to apply such new means of education in their teaching methods. Modern world has imposed several obstacles and prohibited EFL/ESL from achieving their goals. The first and perhaps the most serious one seems to be the lack of time. Great amount of distance, heavy traffic, big tuitions, and fatigue as a result of commuting are some other obstacles on the way of learning foreign languages. In addition, many learners expect newer and more interesting ways of learning a second or foreign language. It seems that new technologies can compensate for this lack of interest.

Electronic-learning seems profitable and interesting. Saving time, energy and money are some outstanding advantages of this new way of education and learning. Electronic-mailing (emailing) is regarded as a subcategory of electronic-learning (e-learning) in which learners send and receive messages, tasks or other items through emails. The purpose of this study is to blend extra emailing tasks with the usual traditional reading comprehension instruction to determine the effects of emailing tasks on reading comprehension ability of Iranian pre-intermediate learners.

\section{REVIEW OF LITERATURE}

We can provide opportunities and prepare our students to work independently through different ways such as teacher selectivity, monitoring, and appropriate adaptability. Ho Mei Lin (1997) maintains that language teachers are responsible to find effective ways to expand learners' opportunities for better learning. He adds that when students become actively engaged in discovering information, they can solve problems and learn on their own which promotes autonomy in return. He also maintains that "Today, information technology (IT) effectively enhances independent learning in our classrooms and can be used as an integral part of classroom instruction" (p. 12).

Whether a student can be successful in learning a foreign language is determined by many factors. Hsia \& Chuang (2002), Hsia \& Hattersly (2004), Chang (2003), and Shih (1982) all agree that "theoretically, foreign language learners can learn a foreign language well so long as they are provided with a good language learning environment, plenty of study time, strong motivation, effective teaching/learning methods and strategies, enough teaching materials, and a thoughtful teacher who recognizes learners' needs" (as cited in Tseng-Chih Chang, et al, 2007, para. 3).

The role of technology in second language learning has increased dramatically throughout the world over the past decade. These technologies, as Gill (2006) believes, include such elements as "the use of Power Point, email exchanges, web based activities, and synchronous and asynchronous communication (through the use of threaded discussion boards, live chat, and virtual communities)" (p. 19). Such a new environment can be incorporated to EFL/ESL classrooms to achieve more stimulating course materials, attempt more variety of learning styles, access more authentic materials on World Wide Web, and promote online communication in target language.

Reading is a considered as a process involving the activation of relevant knowledge and related language skills to accomplish an exchange of information from one person to another, (Chastain 1988). He continued that "reading 
requires that the reader focuses attention on the reading materials and integrates previously acquired knowledge and skills to comprehend what someone else has written" (p.216).

There is an increasing interest in foreign language reading research and how technology influences reading all over the world. Gill (2006) reports a statistically relevant increase in listening and reading comprehension skills within the technology-enhanced courses. She maintains that technology, when used correctly, is a powerful tool to provide students with the opportunity to (1) become more global and (2) develop higher level critical thinking skills (p.27).

However, further research is required on the particular features of emailing to foster L2 acquisition in the FL classroom. González-Bueno (1998) pointed out that such studies should incorporate careful documentation of the learning process present in the use of email in a L2, a well-motivated measure of the learners' language performance and development, and the observation of learners' behavior after manipulating the identified features of email in L2. In a similar research on the effects of emailing on Spanish L2 discourse, he found that use of emails in L2 classes can enhances participation and improves time/space management, with implications for the quality and amount of content.

Rozgiene et al. (2008) phrased that the thing which makes teachers who are used to a face-to-face teaching environment worried is that learners in technology or web-enhanced language learning (TELL/WELL) can misuse the situation in which they are not under the control of the teacher. However, in adult education usually people who opt for this kind of education do this voluntarily, on the basis of self-investment and we should rely on their best intentions to participate in the course. Rozgiene et al. also emphasized that TELL motivates students by letting them "decide about their study time and the conditions they will run the tasks and organize their study process regardless of whether the other participants of the course follow the same line" ( p.17).

González-Bueno (1998) maintained that one of the most important "social effects of computer-mediated communication is a high degree of participation over face-to-face communication" (p. 59). Besides, Gonglewski et al. (2001) emphasized that e-mail could help learners extend what they can do in the classroom and provide a venue for meeting and communicating in the foreign language outside of class context. The nature of e-mail, as he adds, provides the opportunity for learners so that FL learners do not have to be in a specific classroom at a particular time of day in order to communicate with others in the foreign language. According to Rozgiene et al. (2008), there are certainly some learners who welcome a higher degree of freedom in their learning process. As they strongly believe, since learners are naturally anxious and eager to work in the new TELL environment, they can benefit from a couple of strategies such as regular feedback, autonomy development, learning styles awareness, and sharing experience and interaction with others.

Dreyer and Nel (2003) showed that students can benefit from strategic reading instruction offered in TELL. The results of their study indicated that students who received strategic reading instruction in TELL could get both statistically and practically significantly higher marks on three reading comprehension measures than did the students in the control group.

To achieve the goal of this study, the following research questions and null hypotheses were posed:

Q1. Do emailing tasks have any effect on the reading comprehension ability of Iranian pre intermediate EFL learners?

Q2. Do emailing tasks have any effect on Iranian pre intermediate EFL learners' performances on seen and unseen passages?

H1. Emailing tasks have no positive or negative effect on the reading comprehension ability of Iranian pre intermediate EFL learners?

H2. Emailing tasks have no positive and negative effect on Iranian pre intermediate EFL learners' performances on seen and unseen passages?

\section{METHOD}

\section{A. Subjects}

The participants in this study were pre-intermediate EFL Iranian students who took classes in Ferdowsi Language School, Mashhad, Iran. Since school followed segregated educational system, all male and female adult participants (N $=51$ ), aged 18 to 30, had to attend 4 separated classes. Two classes ( $\mathrm{N}=26,12$ males and 14 females) were chosen as the control group and two other classes $(\mathrm{N}=25,12$ males and 13 females $)$ as the experimental group.

\section{B. Instrumentation}

To collect the required data, several instruments were employed in this study:

(1) Interchange/Passages Objective Placement Test. In order to make sure that all participants were homogeneous and truly at the same level of language proficiency, the Interchange/Passages Objective Placement Test, version $\mathrm{C}$ (IPOPT/C) developed by Lesley et al, (2005) was administered. This test had three main sections including listening (20), reading (20), and language use (30) sections. Learners were supposed to gain scores between 18 and 23 out of 70. Participants were supposed to gain scores between 18 and 23 in order to be suitable for pre-intermediate level according to the scoring guidelines of this instrument. Learners in this range of scores were placed at level 4 in which they are taught the second half of Interchange book series one. Two classes were randomly selected as control, one male and one female, and the two other classes as experimental groups, one male and one female. The reading section (20 items) of this test was regarded as pretest so that learners 'progress in reading ability could be determined by comparing learners' 
pretest and posttest scores of this section. The reliability of IPOPT/C, computed through Cronbach's Alpha, was high (r $=.854)$.

(2) Information Technology (IT) Inventory. Since the treatment in experimental group included reading tasks through emails, the researcher had to determine learners' degree of familiarity with the Internet. To serve this purpose, participants in experimental groups were asked to fill out an IT inventory. This inventory consisted of three sections with the total number of 58 items. To avoid any misunderstanding, the questionnaire was presented in Persian. Motallebzadeh and Ghaemi (2009) reported a relatively high reliability for the Persian version as $(\mathrm{r}=.75)$.

(3) Researcher-made Posttest. To measure degree of achievement during the course, a 50-item reading comprehension posttest was employed. This test consisted of three different sections: the first section including 20 items was exactly the reading section of IPOPT/C which was administered again at the end of the course in order to measure the progress of the learners' reading comprehension ability. Two unseen passages with 20 tasks and one seen passage with 10 tasks formed the second and third sections of this reading comprehension posttest. The seen items were selected from among reading comprehension tasks applied during the course. The researcher-made sections of this test were piloted with 25 participants of the same level and an internal consistency of $(r=.72)$ was estimated through Cronbach's Alpha.

\section{Procedure}

The treatment lasted 5 weeks, 3 sessions a week, excluding the sessions assigned for the tests. Among the four groups $(\mathrm{N}=52)$, two were selected as control, one male $(\mathrm{N}=12)$ and one female $(\mathrm{N}=14)$, and the other two groups as experimental, one male $(\mathrm{N}=12)$ and one female $(\mathrm{N}=14)$, randomly. To ensure the homogeneity of the groups at the outset of the study, all participants took IPOPT/C (2005). Participants in experimental groups $(\mathrm{N}=26)$ took an IT questionnaire before the treatment. Only one female proved to be unfamiliar with the basics of IT and emailing; she was transferred to another class and 25 participants formed excremental groups (12 males and 13 females).

During the course the participants were given 10 reading passages, two passages per week, along with ten reading comprehension tasks for each. The passages which were used as extra reading comprehension passages and tasks were carefully selected. This selection regarded similarity in readability and themes. Participants in both control and experimental groups attended conventional classes and took extra reading passages. While learners in experimental groups received extra passages through emails, those in control groups received the same passages in print. The researcher provided the participants in experimental groups an email address and asked all to send him a reply email containing their first and last names as the first step in the treatment.

Participants in control groups received a passage along with ten reading comprehension tasks in print at the end of each session, twice a week. They took this reading comprehension activity home and brought it back the next session with tasks done. Then they had discussions about that passage in the class and the correct answers were given by the teacher with the help of learners. On the other hand learners in experimental groups received a passage along with ten reading comprehension tasks through email after each session. The teacher determined a deadline for each extra reading comprehension activity. Then all learners sent the teacher their tasks done. The teacher corrected them and sent back the correct answers to them.

\section{RESULTS AND DISCUSSIONS}

Having collected the required data based on the above mentioned data collection instruments and procedures, the researcher conducted the analysis of data and tested the hypothesis formulated for the present study.

\section{A. Results of Homogenizing Test}

To compare the participants' level of language proficiency at the beginning of the study in experimental and control groups, an independent-sample t-test was conducted. (see Table 1).

TABLE 1:

RESULTS OF T-TEST ANALYSIS FOR IPOPT/C (HOMOGENIZING TEST)

\begin{tabular}{lllllll}
\hline Groups & $\mathrm{N}$ & $\mathrm{M}$ & $\mathrm{SD}$ & $\mathrm{t}$ & $\mathrm{df}$ & $p$ \\
\hline Cont. & 26 & 20.50 & 1.72 & -.04 & 49 & .97 \\
Exp. & 25 & 20.52 & 1.80 & & & \\
\hline
\end{tabular}

As the results of Table 1 shows, there is no statistically significant difference $[t(49)=-.04, p=0.97$ (two-tailed) $]$ between control $(M=20.50, S D=1.72)$ and experimental $(M=20.52, S D=1.80)$ groups with regard to language proficiency which confirms the homogeneity of the participants at the outset of the study.

Also, a t-test analysis was used to determine the homogeneity of the participants' reading comprehension ability before the treatment begins. Table 2 summarizes the results for this analysis. 
TABLE 2:

RESULTS OF T-TEST ANALYSIS FOR READING COMPREHENSION SECTION OF IPOPT/C

\begin{tabular}{lllllll}
\hline Groups & $\mathrm{N}$ & $\mathrm{M}$ & $\mathrm{SD}$ & $\mathrm{t}$ & $\mathrm{Df}$ & $p$ \\
\hline Cont. & 26 & 6.73 & 2.67 & -.17 & 49 & .87 \\
Exp. & 25 & 6.84 & 1.98 & & & \\
\hline
\end{tabular}

As Table 2 indicates, there is no significant difference $[t(49)=-.17, p=0.87$ (two-tailed) $]$ between control $(M=6.73$, $S D=2.67)$ and experimental $(M=6.84, S D=1.98)$ groups which confirms that the participants possessed similar reading ability before the treatment.

Due to the segregated educational system of the language school, the researcher used a t-test analysis to see if male and female participants were of similar level of reading proficiency at the outset of the study. Tables 3 and 4 show the results for both control and experimental groups.

TABLE 3:

RESULTS OF T-TEST ANALYSIS FOR READING SECTION OF IPOPT/C BETWEEN MALES \& FEMALES (CONTROL GROUP)

\begin{tabular}{lllllll}
\hline Groups & $\mathrm{N}$ & $\mathrm{M}$ & $\mathrm{SD}$ & $\mathrm{t}$ & $\mathrm{df}$ & $p$ \\
\hline Male & 12 & 7.08 & 3.03 & -.61 & 24 & .54 \\
Female & 14 & 6.43 & 2.38 & & & \\
\hline
\end{tabular}

TABLE 4:

RESULTS OF T-TEST ANALYSIS FOR READING SECTION OF IPOPT/C BETWEEN MALES \& FEMALES (EXPERIMENTAL GROUP)

\begin{tabular}{lllllll}
\hline Groups & $\mathrm{N}$ & $\mathrm{M}$ & $\mathrm{SD}$ & $\mathrm{t}$ & $\mathrm{df}$ & $p$ \\
\hline Male & 12 & 6.92 & 2.19 & -.18 & 23 & .86 \\
Female & 13 & 6.77 & 1.83 & & & \\
\hline
\end{tabular}

As Table 3 reveals, no significant difference $[t(24)=-.61, p=0.54$ (two-tailed) $]$ is found between male $(M=7.08$, $S D=3.03)$ and female $(M=6.43, S D=2.38)$ participants' scores in control group before the treatment begins. Also, as Table 4 shows, a significant difference $[t(23)=-.18, p=0.86$ (two-tailed) $]$ is found between the scores of male $(M=$ $6.92, S D=2.19)$ and female $(M=6.77, S D=1.83)$ participants in experimental group before the treatment begins. This proves that male and female participants were similar in reading proficiency at the beginning of the study.

\section{B. Results of Reading Comprehension Tests (Posttest)}

As mentioned in instrumentation, the reading comprehension test in this study included three sections: reading section of IPOPT/C, two unseen passages, and one seen passage. To compare participants' performances in pretest and posttest on one hand and the performances of control and experimental groups on the other, the researcher conducted $t$ tests for their scores in the reading comprehension test as a whole and its separate sections.

Since this research investigated the effect of emailing tasks on reading comprehension ability of the participants, the researcher regarded the reading section of IPOPT/C as pretest and administered the same section at the end of the course as a part of the posttest. Comparing participants' scores in the reading section of IPOPT/C in pretest and posttest, the researcher found that learners in experimental groups gained higher scores than the learners did in control groups in posttest (See Table 5 for the results).

TABLE 5:

RESULTS OF T-TEST ANALYSIS FOR READING SECTION OF IPOPT/C BEFORE \& AFTER TREATMENT

\begin{tabular}{lllllll}
\hline Groups & $\mathrm{N}$ & $\mathrm{M}$ & $\mathrm{SD}$ & $\mathrm{t}$ & $\mathrm{df}$ & $P$ \\
\hline Cont. & 26 & 9.41 & 3.45 & 2.25 & 49 & .03 \\
Exp. & 25 & 16.33 & 2.39 & & & \\
\hline
\end{tabular}

As Table 5 reveals, participants in experimental groups $(M=16.33, S D=2.39)$ significantly outperformed $[t(49)=$ $2.25, p=.03$ (two-tailed)] those in control groups $(M=9.41, S D=3.45)$ in reading section of the IPOPT/C.

To compare the performances of the participants in the other two sections (seen and unseen) of the posttest, $t$-test analysis was conducted. Tables 6 and 7 show the results.

TABLE 6:

RESULTS OF T-TEST ANALYSIS FOR THE READING COMPREHENSION (SEEN SECTION) OF POSTTEST

\begin{tabular}{lllllll}
\hline Groups & $\mathrm{N}$ & $\mathrm{M}$ & $\mathrm{SD}$ & $\mathrm{t}$ & $\mathrm{df}$ & $p$ \\
\hline Cont. & 26 & 7.27 & 1.76 & -2.80 & 49 & .007 \\
Exp. & 25 & 8.52 & 1.42 & & & \\
\hline
\end{tabular}

As the results in Table 6 show, participants' scores in experimental groups $(M=8.52, S D=1.42)$ are much higher than those in control groups $(M=7.27, S D=1.76)$ and reflect a significant difference $[t(49)=2.80, p=.007$ (twotailed)]. 
TABLE 7:

RESULTS OF T-TEST ANALYSIS FOR READING COMPREHENSION (UNSEEN SECTION) OF THE POSTTEST

\begin{tabular}{lllllll}
\hline Groups & $\mathrm{N}$ & $\mathrm{M}$ & $\mathrm{SD}$ & $\mathrm{t}$ & $\mathrm{df}$ & $P$ \\
\hline Cont. & 26 & 5.58 & .87 & -.08 & 49 & .94 \\
Exp. & 25 & 5.60 & 1.18 & & & \\
\hline
\end{tabular}

As Table 7 indicates, there is no significant difference $[\mathrm{t}(49)=-.08, \mathrm{p}=.94$ (two-tailed)] between the performances of experimental $(\mathrm{M}=5.58, \mathrm{SD}=.87)$ and control $(\mathrm{M}=5.60, \mathrm{SD}=1.18)$ groups over the unseen section of posttest.

In order to compare the performances of the participants in experimental and control groups over the whole test and examine the effect of the treatment, a t-test analysis was used. Table 8 summarizes the results for this analysis.

TABLE 8:

RESULTS OF T-TEST FOR THE WHOLE POSTTEST

\begin{tabular}{lllllll}
\hline Groups & $\mathrm{N}$ & $\mathrm{M}$ & $\mathrm{SD}$ & $\mathrm{T}$ & $\mathrm{df}$ & $P$ \\
\hline Cont. & 26 & 24.58 & 2.41 & -4.34 & 49 & .00 \\
Exp. & 25 & 28.08 & 3.31 & & & \\
\hline
\end{tabular}

According to results in Table 8, participants in experimental groups $(M=28.08, S D=3.31)$, receiving emailing tasks, outperformed much higher than those in control groups $(M=24.58, S D=2.41)$ indicating a significant difference $[t(49)$ $=-4.43, p=.00$ (two-tailed)].

To test the probable effect of gender on the final results, a t-test analysis was carried out between the performances of males and females in the posttest. Tables 9 and 10 show the results.

TABLE 9:

RESULTS OF T-TEST ANALYSIS FOR THE POSTTEST BETWEEN MALES \& FEMALES (CONTROL GROUP)

\begin{tabular}{lllllll}
\hline Groups & $\mathrm{N}$ & $\mathrm{M}$ & $\mathrm{SD}$ & $\mathrm{t}$ & $\mathrm{df}$ & $p$ \\
\hline Male & 12 & 24.58 & 3.30 & .27 & 24 & .79 \\
Female & 14 & 24.57 & 1.39 & & & \\
\hline
\end{tabular}

TABLE 10:

RESULTS OF T-TEST ANALYSIS FOR THE POSTTEST BETWEEN MALES \& FEMALES (EXPERIMENTAL GROUP)

\begin{tabular}{lllllll}
\hline Groups & $\mathrm{N}$ & $\mathrm{M}$ & $\mathrm{SD}$ & $\mathrm{t}$ & $\mathrm{df}$ & $p$ \\
\hline Male & 12 & 27.71 & 3.08 & -.21 & 23 & .83 \\
Female & 13 & 28.42 & 3.60 & & & \\
\hline
\end{tabular}

As the results in Table 9 indicate, no significant difference $[t(24)=.27, p=.79$ (two-tailed) $]$ is found between males $(M=24.58, S D=3.30)$ and females $(M=24.57, S D=1.39)$ in control groups. In addition, the results in Table 10 show that male participants $(M=27.71, S D=3.08)$ have performed similarly to female participants $(M=28.42, S D=3.60)$ in experimental groups reflecting no significant difference $[t(23)=-.21, p=.83$ (two-tailed)].

\section{CONCLUSIONS AND PEDAGOGICAL IMPLICATIONS}

As the data analysis indicated, emailing task seems to have a significant effect on the improvement of reading comprehension ability of Iranian EFL learners. It is also concluded that gender has little or no significant effect on the development of reading proficiency via web-enhance language learning (WELL) programs. Findings of the study also showed no significant difference between the participants' performances on unseen passages section of the posttest implying that the achievement in reading comprehension can be limited to reading texts practiced via emailing.

In addition, like similar researches on technology enhanced language learning (TELL) conducted by Volle, 2005; Gonglewski et al., 2001; and Li, 2000, it appears that this experience was successful in accomplishing its intended goal of providing opportunities for Iranian pre-intermediate learners to engage in sending and receiving emails for classroom reading tasks. Besides, this study seems similar to the blended programs in which traditional face to face classes and web-enhanced programs are held side by side. However, it is clear that learners who are not familiar with such a novel environment need more time to adapt themselves.

Nowadays emailing is becoming quite common among school and university students in Iran although internet connection speed and lack of expertise on the part of both students and teachers are the major drawbacks of the new innovation. Hence, emailing tasks, provided that they are designed appropriately, can be considered as an innovative approach to language learning and seems applicable to particularly private language schools. The results of this research suggest that other school subjects rather than language could also be practiced through emailing. Finally, due to the findings of this study on the prerequisite IT knowledge, it can be concluded that those learners who are more dominant and proficient net-users can benefit more from WELL/TELL.

\section{ACKNOWLEDGEMENT}

I would like to thank three anonymous reviewers for heir helpful comments on the earlier draft of this paper. 


\section{REFERENCES}

[1] Belisle, R. (1996). Email activities in the ESL writing class. The Internet TESL Journal, 2(12). Retrieved June 2, 2010, from http://iteslj.org/Articles/Belisle-Email.html

[2] Chang, T., Chang, C., Su, Y., \& Chen, F. (2007). Enhancing the English learn effectiveness of $8^{\text {th }}$ grade students using an online interactive English system. World Transactions on Engineering and Technology Education, 6(1). Retrieved February 2010, from Elsevier database.

[3] Chastain, K. (1988). Developing second-language skills: theory and practice. US: Harcourt Brace Jovanovich.

[4] Dreyer, C., \& Nel, C. (2003). Teaching reading strategies and reading comprehension within a technology-enhanced learning environment. System, 31, 349-365.

[5] Gill, Deborah. (2006). Effects of Technology on Second Language Learning. Journal of College Teaching \& Learning, 3(2), 19-28.

[6] Gonglewski, M., Meloni, C., \& Brant, J. (2001). Using email in foreign language teaching: Rational and suggestions. The Internet TESL Journal, 7(3). Retrieved February 28, 2010, from http://iteslj.org/

[7] González-Bueno, M. (1998). The effects of electronic mail on Spanish L2 discourse. Language Learning \& Technology, 1(2), 55-70. Retrieved March 2, 2010, from http://ltt.msu.edu/vol1num2/article3/

[8] Ho Mei Lin, C. (1997). Teacher's tips: Online grammar teaching and learning. The Internet TESL Journal, 3(12). Retrieved June 11, 2010, from http://iteslj.org/Articles/Lin-OnlineGrammar.html

[9] Lesley, T., Hanson, C., \& Zukowski, J. (2005). New Interchange/Passages Placement and Evaluation Package. Cambridge: CUP.

[10] Li, Y. (2000). Linguistic characteristics of ESL writing in task-based email activities. System, 28, 229-245. Retrieved from Elsevier database.

[11] Motallebzadeh, K., \& Ghaemi, H. (2009). The relationship between on-line reading strategies and the choice of off-line reading strategies of Iranian intermediate EFL learners. The Iranian EFL Journal, 3, 64-81. Retrieved August 19, 2010, from http://www.iranian-efl-journal.com

[12] Rozgiene, R., Medvedeva, O., \& Straková, Z. (2008). Integrating ICT into language learning and teaching: Guide for tutors. Retrieved April 29, 2010, from http://www.elearningguides.net/guides/3b-GUIDES-TUTORS-EN.pdf

[13] Volle, L. M. (2005). Analyzing oral skills in voice email and online interviews. Language Learning \& Technology, 9(3), 146163. Retrieved February 26, 2009, from http://Ilt.msu.edu/vol9num3/volle/

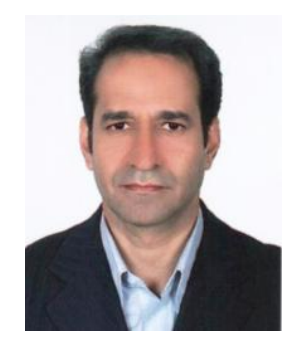

Khalil Motallebzadeh was born in Iran in 1964. He received a PhD in Teaching English as a Foreign Language (TEFL) from Islamic Azad University, Science and Research Campus, Tehran, Iran, in 2000, an MA in TEFL from Tarbiat Modarres University, Tehran, Iran, in 1992 and a BA in TEFL from the University for Teacher Education, Tehran, Iran, in 1990.

As for his professional background, he has been teaching English since 1985 and at present is assistant professor at Islamic Azad University (IAU) of Torbat-e-Heidarieh and Mashhad Branches, Iran. He has been a visiting scholar at the University of Illinois at Urbana Champaign (UIUC) in 2007-2008. Khalil has published several papers in different areas in national and international journals, and given presentations on TEFL at many international conferences. He is especially interested in language testing, teacher education, and e-learning.

Dr. Motallebzadeh is a member of IATEFL and an accredited teacher trainer of the British Council since 2008 and is currently the Iran representative of Asia TEFL. 